\title{
Gene amplification in carcinogenesis
}

\author{
Lucimari Bizari $^{1}$, Ana Elizabete Silva ${ }^{1}$ and Eloiza H. Tajara ${ }^{2}$ \\ ${ }^{1}$ Universidade Estadual Paulista, Departamento de Biologia, São José do Rio Preto, SP, Brazil. \\ ${ }^{2}$ Faculdade de Medicina de São José do Rio Preto, Departamento de Biologia Molecular, \\ São José do Rio Preto, SP, Brazil.
}

\begin{abstract}
Gene amplification increases the number of genes in a genome and can give rise to karyotype abnormalities called double minutes (DM) and homogeneously staining regions (HSR), both of which have been widely observed in human tumors but are also known to play a major role during embryonic development due to the fact that they are responsible for the programmed increase of gene expression. The etiology of gene amplification during carcinogenesis is not yet completely understood but can be considered a result of genetic instability. Gene amplification leads to an increase in protein expression and provides a selective advantage during cell growth. Oncogenes such as CCND1, $c-M E T, c-M Y C, E R B B 2$, EGFR and MDM2 are amplified in human tumors and can be associated with increased expression of their respective proteins or not. In general, gene amplification is associated with more aggressive tumors, metastases, resistance to chemotherapy and a decrease in the period during which the patient stays free of the disease. This review discusses the major role of gene amplification in the progression of carcinomas, formation of genetic markers and as possible therapeutic targets for the development of drugs for the treatment of some types of tumors.
\end{abstract}

Key words: gene amplification, gene expression, oncogenes, carcinomas, double minutes.

Received: October 21, 2004; Accepted: August 1, 2005.

\section{Gene Amplification}

\section{Structural characteristics of amplified genes}

Gene amplification can be defined as an expansion in the number of copies of a gene in the cell genome which occurs by replication of the genomic DNA to produce karyotype abnormalities called double minutes (DM) and homogeneously staining regions (HSR) (Bast et al., 2000; Simon et al., 2002). Such gene amplification should be considered separately from chromosome aneuploidy, which is outside the scope of this review.

Double minutes are extrachromosomal circles of DNA containing 1 to 2 million base pairs which replicate autonomously about once every cell cycle and, because they have no centromeres, segregate at random to the daughter cells. In contrast, homogeneously staining regions are intrachromosomal segments forming large genomic regions (Hellman et al., 2002) which display no chromosome banding pattern when submitted to G-banding but can be detected by fluorescence in situ hybridization (FISH). Both

Send correspondence to Eloiza H. Tajara. Faculdade de Medicina de São José do Rio Preto, Departamento de Biologia Molecular, 15.090-000 São José do Rio Preto, SP, Brazil. E-mail: tajara@ famerp.br these structures have amplified genomic DNA, containing hundreds of copies of one or more genes, frequently oncogenes (Bast et al., 2000).

\section{Gene amplification during development}

Gene amplification plays a major role during development when it is responsible for the programmed increase of gene expression. For example, because amphibian oocytes require high levels of proteins genes responsible for ribosomal RNA (rRNA) are amplified to produce between two thousand and one million copies of rRNA per oocyte. Other examples are the amplification of genes responsible for chorionic proteins in Drosophila oocytes (Cooper, $2000)$ and the amplification of the $L A C$ allele region in Escherichia coli growing under conditions of environmental stress such as lactose deficiency, such amplification resulting in higher production of the enzyme lactase enabling the bacteria to grow even in a restrictive environment (Hastings and Rosenberg, 2002).

\section{Gene amplification in carcinogenesis}

Gene amplification involving double minutes and homogeneously staining regions has been widely observed in human tumors in which these processes act as one of the 
oncogene-activating genetic mechanisms (Bast et al., 2000; Imoto et al., 2001) and frequently suggests an aggressive behavior of the tumor and a poor prognosis (Ohta et al., 2001; Ethier et al., 2003). Exact data on the frequency of double minutes and homogeneously staining regions in tumor cells in vivo are difficult to obtain since these abnormalities are easily missed in routine cytogenetic analysis. Also, the percentage of cells expressing double minutes or homogeneously staining regions varies widely. Both events are seen more frequently in established cell lines than in primary tumors (Schwab et al., 1999) and homogeneously staining regions more frequently in advanced stages of tumors (Schwab et al., 1999).

The etiology of gene amplification in cancer is not yet completely understood, but it can be considered a result of genetic instability. Cytogenetic studies of rat drug resistance genes indicate that chromosome breaks followed by fusion of distant segments and the consequent formation of anaphase bridges frequently occur in tumor cells (Hellman et al., 2002), this process being particularly common at certain fragile sites which are unstable chromosomic regions prone to breaks or gaps during cell division. Hypoxia is a powerful fragile site inducer and is thought to facilitate the fusion of double minutes and their reintegration into the chromosomal fragile sites to produce homogeneously staining regions (Ishizuka et al., 2002).

Gene amplification leads to an increase in gene expression and this can confer a selective advantage during the early stages of the neoplastic process. However, amplification may also occur as a late tumorigenesis event (Tsujimoto et al., 1997; Bast et al., 2000; Sarasin, 2003). Although gene amplification appears to be the main mechanism leading to protein overexpression in carcinogenesis the gain of gene copies by polysomy may also result in high protein levels, as has been reported for breast (Lal et al., 2003), esophageal and gastric carcinomas with positive immuno-staining but no amplification (Bizari et al., in press).

\section{Main Amplified Genes in Human Neoplasias}

Several studies have shown that some oncogenes (e.g. $C C N D 1, c-M E T$, c-MYC, ERBB2, EGFR and MDM2) are amplified in a significant number of human tumors. These and other oncogenes rarely become amplified alone but rather present as large amplicons with multiple copies of several genes, making it difficult to establish which of these genes provide a proliferative advantage (Nakakuki et al., 2002; Simon et al., 2002; Ethier, 2003).

The MYCN oncogene localized at 2p23-24 is a member of the MYC-box group of genes (Schwab et al., 1988) and encodes a $65 \mathrm{kDa}$ transcriptional factor (Ramsay et al., 1986; Slamon et al., 1986; Schwab et al., 2004). The basic mechanism for MYCN protein activity involves formation of a mandatory heterodimer with a nuclear phosphoprotein called MAX (Facchini et al., 1998). This heterodimer binds to specific DNA E-box elements to initiate target gene transcription. Due to its association with aggressively growing tumor phenotypes $M Y C N$ was the first clinically significance oncogene amplified (Schwab et al., 1995). Amplification of the $M Y C N$ oncogene occurs as double minutes or homogeneously staining regions and has been found only in more aggressive variants of neuroblastoma where it indicates a bad clinical prognosis (Rubie et al., 1997; Solovei et al., 2000; Perel et al., 2004; Schwab et al., 2004). Conversely, the expression of $M Y C N$ without amplification is a normal feature of cells of various tissues including retinal (Squire et al., 1986) and kidney (Zimmerman et al., 1986) tissue. In neuroblastoma no correlation between MYCN overexpression and amplification has been observed (Vasudevan et al., 2005).

The MYCN amplicon can be up to $1 \mathrm{Mb}$ in size and so could contain additional genes that affect tumor phenotype. The $D D X 1$ gene is frequently co-amplified with $M Y C N$ in neuroblastoma (Scott et al., 2003) and in 50-70\% of different primary tumors and in about $70 \%$ of cell lines (George et al., 2000; Preter et al., 2002). The DDX1 gene maps $340 \mathrm{~kb}$ telomeric to the $M Y C N$ gene (George et al., 2000) and encodes a $2.7-\mathrm{kb}$ transcript with a predicted protein product of 740 amino acids. A poorer prognosis has been observed with $D D X 1$ co-amplification (Squire et al., 1995) but other workers have reported no significant difference in clinical presentation or outcome (Manohar et al. 1995) or even a better prognosis and improved patient survival (Weber et al., 2004).

Other genes co-amplified in tumors include $M D M 2$ and CDK4, mapped at 12q14-15 (Wunder et al., 2000; Lopez-Guerrero et al., 2004; Pedeutour et al., 2004) and CCND, INT-2, EMS1 and HST-1, mapped at 11q13. The $11 \mathrm{q} 13$ amplicon can vary in size from less than 1 to $4.5 \mathrm{Mb}$ and recent data have identified four core regions within $11 \mathrm{q} 13$ that can be amplified independently or together in different combinations (Tanner et al., 1996; Ormandy et al., 2003). This group of genes is frequently amplified in breast, bladder, head and neck, lung and esophageal squamous cell carcinomas (Huang et al., 2002; Ishizuka et al., 2002). Among these, CCND1 is the most frequently amplified gene in tumor cells (Nagasawa et al., 2001; Huang et al., 2002; Miyamoto et al., 2003). Overexpression of the Cyclin D1 protein also occurs in these cases, but it may or may not be related to gene amplification (Miyamoto et al., 2003; Moreno-Bueno et al., 2003).

Cyclin D1 is a $38 \mathrm{kDa}$ protein belonging to the cyclin D family which includes cyclins D2 and D3 (Ewen and Lamb, 2004). The D1 cyclin regulates the transition of cells from the G1 phase to the S phase by phosphorylation of the $\mathrm{pRb}$ protein during the G1 phase and the release of the family of E2F transcription factors (Rabbani et al., 2000; Brandau et al., 2001; Vielba et al., 2003) which in turn lead to the induction of the genes needed for the G1-S cell cycle transition (Ewen and Lamb, 2004). Cyclin D1 acts by form- 
ing the D1 cyclin/cyclin-dependent protein kinase (CDK) complex D1-CDK which activates specific CDKs (CDK4 and CDK6) which allow the cell cycle to progress (Rabbani et al., 2000; Saikawa et al., 2001) (Figure 1). Amplification of the gene encoding the D1 cyclin is seen in a variety of solid tumors, including breast adenocarcinoma, squamous cell carcinoma of head and neck, esophageal and bladder cancer (Ewen and Lamb, 2004). In bladder tumors, overexpression of the D1 cyclin protein is correlated with highdegree tumors and a short recurrence time but no association between tumor invasion or decreased survival and Cyclin D1 overexpression has been detected (Adshead et al., 1998).

Amplification of the CCND1 oncogene also occurs in the early stages of these tumors and persists during the advanced stages of the disease, although the exact mechanism leading to progression remains unclear (Watters et al., 2002). In esophageal squamous cell carcinomas and adenocarcinomas and in head and neck and larynx tumors, amplification of the CCND1 oncogene is also related to a poor prognosis, including local invasion, metastases in lymph nodes, an advanced stage of the disease and an increased recurrence risk (Nagasawa et al., 2001; Ishizuka et al., 2002; Ozawa et al., 2002; Nadal et al., 2003; Miller et al., 2003; Miyamoto et al., 2003). Both the amplification of the oncogene and the overexpression of the D1 cyclin also seem to be related to the resistance of esophageal tumors to chemotherapeutic agents (Nagasawa et al., 2001). In esophageal carcinomas, it has been shown that gene amplification of homogeneously staining regions, as opposed to polysomy, was the main mechanism responsible for overexpression of the Cyclin D1 protein (Bizari et al., in press).

In breast cancer, both gene amplification and overexpression of the protein Cyclin D1 are related to a shorter survival time, a shorter period free of the disease and a higher tumor recurrence rate (Ormandy et al., 2003).

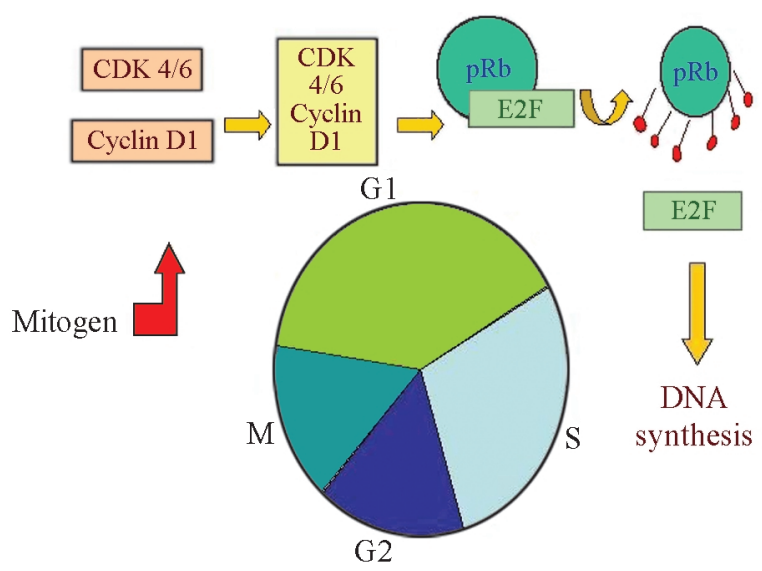

Figure 1 - Simplified G1/S regulation. When a dividing cell is about to go through another round of division, the Rb protein (or its related family members) is phosphorylated by cyclin/CDK complex which releases the E2F transcription factor and leads to changes in gene expression that are essential for cell cycle transition.
Another widely studied amplicon is located in region 7q31-q32 and includes the c-MET oncogene which encodes the hepatocyte growth factor (HGF) receptor (Herynk et $a l ., 2003)$ and is one of the oncogenes most frequently associated with the development of gastric cancer, where it exhibits alterations such as amplification and overexpression of its protein (Nessling et al., 1998). The amplification of this oncogene is correlated with the stage of the tumor (especially for diffuse tumors) and is never found in the early stages of carcinogenesis, because of which the $c-M E T$ oncogene is a marker of poor prognosis and indicates progression and increased metastases (Nessling et al., 1998; Tsugawa et al., 1998; Tahara, 2004).

Gene amplification and deregulation of the expression of the $c-M Y C$ oncogene located in region $8 \mathrm{q} 24$ region are the main activating mechanisms of this oncogene in human tumors (Mai et al., 2003; Abba et al., 2004). Its protein (myc) enables the cell to enter the cell cycle, activating several genes including those encoding ornithine decarboxylase, phosphatase cdc25A and the transcription factor E2F (Zajac-Kaye, 2001; Mai et al., 2003) and repressing others (such as the $\mathrm{p} 27$ releasing protein from the cdk 2 complex) by means of the activity of the cyclin E-cdk2 complex. Once released, the p 27 protein is sequestered by the cdk4cyclin D complex to form a new complex (cdk4-cyclinDp27) able to phosphorylate $\mathrm{pRb}$ and release the E2F transcription factor enabling the cell to perform the G1-S cell cycle transition (Zajac-Kaye, 2001). Overexpression of the c-myc protein can increase cell proliferation, impair differentiation and lead to an increase in cell apoptosis (Abba et al., 2004), although expression of this protein usually decreases when the cell is leaving the cell cycle and during differentiation.

In several types of cancer, such as breast and hepatocellular (Ghani-Abdel et al., 2002; Robanus-Maandag et al., 2003), prostate, cervical (Abba et al., 2004) and lung tumors (Zajac-Kaye et al., 2001; Yakut et al., 2003) c-MYC amplification is correlated with protein overexpression and is frequently associated with more aggressive tumors. In breast cancer, there is an association between $c-M Y C$ amplification and the expression levels of mRNA and its protein (Blancato et al., 2004) but in bladder carcinomas such a correlation is not yet clear, and the gene is also seen amplified in low-grade tumors (Schulz et al., 1998). In cervical carcinoma, $c-M Y C$ amplification occurs in early stages and can lead to tumor progression (Abba et al., 2004). In gastric carcinomas, its overexpression is a major factor that can be used to distinguish between well differentiated adenomas and adenocarcinomas. This alteration is present not only at the beginning of the disease, but seems to be related with its entire course (Kozma et al., 2001).

The ERBB2 gene, also known as HER-2/neu, is mapped to region 17q11-q12 (Yamamoto et al., 1986) and is amplified in tumors of various tissues such as breast, ovary, bladder, stomach and lung (Takehana et al., 2002; Lear- 
Kaul et al., 2003) and is a potential marker of prognosis in some them. This gene encodes a transmembrane phosphoglucoprotein (p185) that resembles the epidermal growth factor receptor (EGFR) which acts as a tyrosine kinase receptor, stimulating cell proliferation (Ohta et al., 2001; Rabbani et al., 2001; Krause et al., 2000) (Figure 2). In breast cancer cell lines, the repetitive unit of the ERBB2 amplicon was identified as a 120 kilobase strech of genomic DNA with structure of homogeneously staining regions (Dahlberg et al., 2004) (Figure 3). In breast cancer, the $17 \mathrm{q} 11$ amplicon harbors the $E R B B 2$ gene and other putative oncogenes (Barlund et al., 1997; Sinclair et al., 2003).

In breast and lung tumors, $E R B B 2$ amplification induces overexpression of the protein in the cell membrane (Ohta et al., 2001; Takehana et al., 2002; Lear-Kaul et al., 2003), which has been associated with a poor prognosis (Ohta et al., 2001; Cianciulli et al., 2003; Hirsch et al., 2003), while overexpression in gastric tumors is related to the presence of metastases (Nessling et al., 1998; Vidgren et al., 1999; Varis et al., 2002) and evolution to the gastric

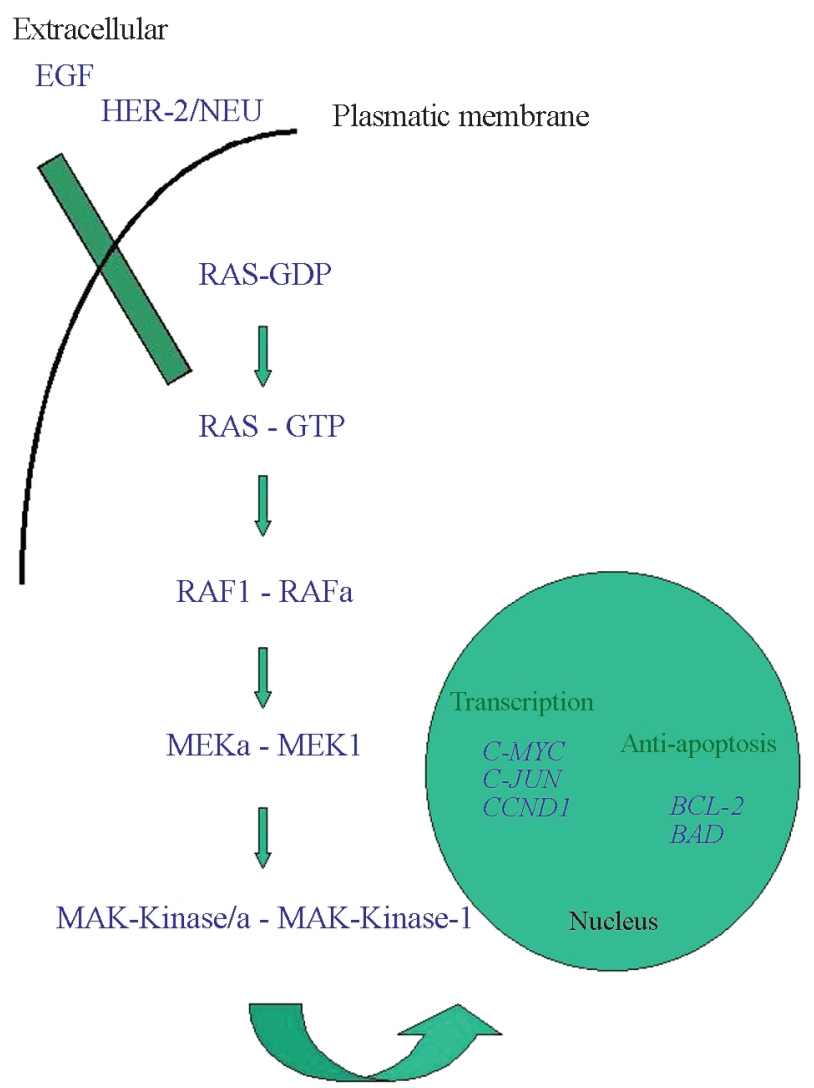

Figure 2 - Activation of epidermal growth factor receptor (EGFR) results in the initiation of a diverse array of cellular pathways. Dimerization results in autophosphorylation, initiating a downstream cascade of events and culminating in cellular responses such as cell proliferation or apoptosis. These protein interactions allowing Ras activation which this activates the RAF-MEK-MAP-kinase signaling pathways which, in turn, activate transcription factors, such as c-fos, c-myc and cyclin D which promote gene expression and contribute to cell proliferation. intestinal type (Becker et al., 2000). Evaluation of ERBB2 gene status has revealed that in both esophageal and gastric cancer high-polysomy, as opposed to gene amplification, was the prevalent pattern regarding a gain in ERBB2 gene copies (Bizari et al., in press; Sunpaweravong et al., 2005).

Amplification of the ERBB2 oncogene, regardless of protein overexpression, has frequently been detected in bladder tumors, although it has not yet been correlated with the development, progression and clinical course of the disease (Adshead et al., 1998; Brandau et al., 2001; Ohta et al., 2001). In these tumors as well as in breast tumors, amplification and overexpression of the c-erbB2/neu protein has been investigated with the purpose of possibly directing the treatment of positive patients towards the use of the monoclonal antibody Herceptin (trastuzumab), since the levels of gene amplification and protein expression are very similar to those found in patients with breast cancer (Ross and McKenna, 2001; Ross and Gray, 2003). Herceptin works as a negative regulator of the c-erbB2/neu protein, inhibiting the signaling pathway of the cell cycle and blocking its transition. In vivo, herceptin inhibits angiogenesis and induces antibody-dependent cell cytotoxicity (Albanell et al., 2003; Menard et al., 2003). Besides Herceptin, other drugs are under study for use in patients with amplification of the $c-M Y C$ and $c-M E T$ oncogenes (Ma et al., 2003). The c-myc protein takes part in several signaling cascades during the cell cycle and appears activated in tumor cells, promoting cell proliferation and regulating the expression of many target genes. Thus, inhibition of $c-M Y C$ expression could be sufficient to block tumor growth and to induce tumor regression (Hermeking et al., 2003).

In conclusion, detailed analyses of genomic structures and sequences of amplified regions have revealed that amplicons exhibit complex patterns and can harbor multiple genes associated with tumorigenesis. The evaluation of

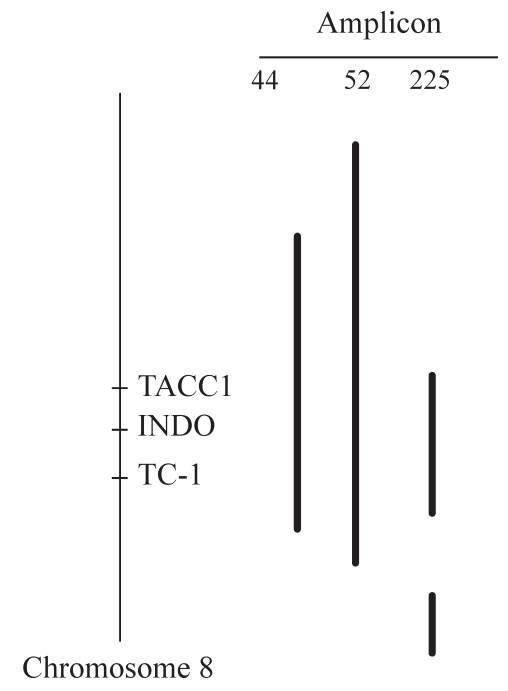

Figure 3 - Ideogram of the 8p11-p12 amplicon in three HBC cell lines, SUM-44, SUM-52 and SUM-225 showing the conserved region (modified from Yang et al., 2004). 
co-amplified genes may provide important insights into the pathogenesis of cancer, and can lead to the identification of targets for novel therapeutics. Gene amplification as double minutes and homogeneously staining regions offers the opportunity for functional studies of candidate oncogenes and also to analyze the factors which drive the neoplastic process, the number of mutations required for malignancy and the selective advantage which tumor cells have acquired during tumorigenesis. For example, comparison of the 8p11-p12 amplicon in different breast cancer cell lines showed a conserved region that may contain more than one important gene for tumor development, including the TACC1, INDO and TC-1 genes (Sunde et al., 2004) (Figure 3 ). The TACC1 gene participates in anchorage-independent growth (Lapin et al., 2002) while INDO mediates immunosuppression (Li et al., 2004) and $T C-1$ is related to apoptotic process during the carcinogenic process (Sunde et al., 2004).

The potential of double minute and homogeneously staining region analysis is far from exhausted. Comparison of amplicons from different samples, fine mapping of the amplified region and functional studies may reveal new pathways associated with tumor growth and the clinical course of the disease. The results can certainly provide new tools in the fight against cancer.

\section{References}

Abba MC, Laguens RM, Dulout FN and Golijow CD (2004) The c-myc activation in cervical carcinomas and HPV 16 infections. Mut Reserch 557:151-158.

Adshead JM, Kessling AM and Ogden CW (1998) Genetic initiation, progression and prognostic markers in transitional cell carcinoma of the bladder: a summary of the structural and transcriptional changes, and the role of developmental genes. Br J Urol 82:503-512.

Albanell J, Codony J, Rovira A, Mellado B and Gascon P (2003) Mechanism of action of anti-HER2 monoclonal antibodies: Scientific update on trastuzumab and 2C4. Adv Exp Med Biol 532:253-268.

Barlund M, Tirkkonen M, Forozan F, Tanner MM, Kallionemi O and Kallionemi A (1997) Increased copy number at 17q22q24 by CGH in breast cancer is due to high level amplification of two separate regions. Genes Chromosomes Cancer 20:372-376.

Bast Robert C, Kufe Donald W, Pollock Raphael E, Weichselbaum Ralph R and Holland James F (2000) Cancer Medicine. 5th edition. BC Decker Inc, Ontario, pp 2546.

Becker KF, Keller G and Hoefler H (2000) The use of molecular biology in diagnosis and prognosis of gastric cancer. Surg Oncol 9:5-11.

Blancato J, Singh B, Liu A, Liao DJ and Dickson RB (2004) Correlation of amplification and overexpression of the c-myc oncogene in high-grade breast cancer: FISH, in situ hybridization and immunohistochemical analyses. Br J Cancer 90:1612-1619.

Brandau S and Bohle A (2001) Bladder cancer. Molecular and Genetic Basis of Carcinogenesis. Eur Urol 39:491-497.
Bizari L, Borim AA, Moreira-Leite KR, Gonçalves FT, Cury PM, Silva AE and Tajara EH (2005) Association between amplification, polysomy and overexpression of the CCND1 and Her-2/neu proteins in esophageal and gastric cancer. Cancer Genet and Cytogenet, in press.

Cianciulli AM, Guadagni F, Benevolo M, Merola R, Giannarelli D, Marandino F, Vocaturo G, Mariani L and Mottelese M (2003) HER-2/neu oncogene amplification and chromosome 17 aneusomy in endometrial carcinoma: correlation with oncoprotein expression and conventional pathological parameters. J Exp Clin Cancer Res 22:265-271.

Cooper GM (2000) The cell: A molecular approach. 2nd edition. Sinauer Associates, Inc., Massachusetts, pp 689.

Dahlberg PS, Jacobson BA, Dahal G, Fink JM, Kratzke RA, Maddaus MA and Ferrin LJ (2004) ERBB2 amplifications in esophageal adenocarcinoma. Ann Thorac Surg 78:17901800.

Ethier SP (2003) Identifying and validating causal genetic alterations in human breast cancer. Breast Cancer Res Treat 78:285-287.

Ewen ME and Lamb J (2004) The activities of cyclin D that drive tumorigenesis. Trends in Mol Medicine 10:158-162.

Facchini LM and Penn LZ (1998) The molecular role of Myc in growth and transformation: Recent discoveries lead to new insights FASEB J 12:633-651.

George RE and Squire J (2000) Structure of the MYCN amplicon. In: Brodeur GM, Sawada T, Tsuchida Y and Voute PA (eds) Neuroblastoma. Elsevier Science BV Amsterdam, pp 85100.

Ghani-Abdel AS, Ghada EA, Naase M and Wells CA (2002) $\mathrm{C}$-myc oncoprotein expression and gene amplification in apocrine metaplasia and apocrine change within sclerosing adenosis of the breast. The breast 11:466-472.

Hellman A, Zlotorynski E, Scherer SW, Cheung J, Vincent JB, Smith DI, Trakhtenbrot L and Kerem B (2002) A role for common fragile site induction in amplification of human oncogenes. Cancer Cell 1:89-97.

Hermeking H (2003) The MYC oncogene as a cancer drug target. Curr Cancer Drug Targets 3:163-175.

Herynk HM, Stoeltzing O, Reinmuth N, Parikh NU, Abounader R, Laterra J, Radinsky R, Ellis LM and Gallick GE (2003) Down-regulation of c-Met inhibits Growth in the liver of human colorectal carcinoma cells. Cancer Res 63:2990-2996.

Hirsch FR, Scagliotti GV, Langer CJ, Varella-Garcia M and Franklin WA (2003) Epidermal growth factor family of receptors in preneoplasia and lung cancer: Perspectives for target therapies. Lung Cancer 41:29-42.

Hastings PJ and Rosenberg SM (2002) In pursuit of a molecular mechanism for adaptive gene amplification. DNA Repair 1:111-123.

Huang X, Gollin SM, Raja S and Godfrey TE (2002) High-resolution mapping of the 11q13 amplicon and identification of a gene, TAOS1, that is amplified and overexpressed in oral cancer cells. PNAS 99:11369-11374.

Imoto I, Yang ZQ, Pimkhaokham A, Tsuda H, Shimada Y, Imamura M, Ohki M and Inazawa J (2001) Identification of cIAP1 as a candidate target gene within an amplicon at $11 \mathrm{q} 22$ in esophageal squamous cell carcinomas. Cancer Res 61:6629-6634.

Ishizuka T, Tanabe C, Sakamoto H, Aoyagi K, Maekawa M, Matsukura N, Tokunaga A, Tajiri T, Yoshida T, Terada M 
and Sasaki H (2002) Gene amplification profiling of esophageal squamous cell carcinomas by DNA array CGH. Biochem Biophys Res Commun 296:152-155.

Kozma L, Kiss I, Hajdu J, Szentkereszty Z, Szakall S and Ember I (2001) C-myc amplification and cluster analysis in human gastric carcinoma. Anticancer Res 21:707-710.

Krause FS, Feil G, Zumbragel A and Bichler KH (2000) Molecular genetic methods in the diagnosis of invasive bladder cancer. Anticancer Research 20:5015-5022.

Lal P, Salazar PA, Ladany M and Chen B (2003) Impact of polysomy 17 on HER-2/neu immunohistochemistry in breast carcinomas without HER-2/neu gene amplification. JMD 5:155-159.

Lappin TR, Mullan RN, Stewart JP, Morgan NA, Thompson A and Maxwell AP (2002) AINT/ERIC/TACC: An expanding family of proteins with $\mathrm{C}$-terminal coiled coil domains. Leuk Lymphoma 43:1455-1459.

Lear-Kaul KC, Yoon HR, Kleinschmidt-DeMasters BK, Mc Gavran L and Singh M (2003) Her-2/neu status in breast cancer metastases to the central nervous system. Arch Pathol Lab Med 127:1451-1457.

Li Y, Tredget EE and Ghahary A (2004) Cell surface expression of MHC class I antigen is suppressed in indoleamine 2,3dioxygenase genetically modified keratinocytes: Implications in allogeneic skin substitute engraftment. Hum Immunol 65:114-23.

Lopez-Guerreiro JÁ, Lopez-Gines C, Pellin A, Carda C and Llombart-Bosch A (2004) Deregulation of the G1 to Sphase cell cycle checkpoint is involved in the pathogenesis of human osteosarcoma. Diagn Mol Pathol 13:81-91.

Ma PC, Maulik G, Christensen J and Salgia R (2003) c-Met structure, functions and potential for therapeutic inhibition. Cancer Metastasis Rev 4:309-325.

Mai S and Mushinski FJ (2003) c-Myc Induced genomic instability. J Environm Pathol Toxicol and Oncol 3:179-199.

Manohar CF, Salwen HR, Brodeur GM and Cohn SL (1995) Co-amplification and concomitant high levels of expression of a DEAD box gene with MYCN in human neuroblastoma. Genes Chromosomes Cancer 14:196-203.

Menard S, Pupa SM, Campiglio M and Tagliabue E (2003) Biologic and therapeutic role of HER-2 in cancer Oncogene 42:6570-6578.

Miller CT, Moy JR, Lin L, Schipper M, Normolle D, Brenner DE, Iannettoni MD, Orringer MB and Beer DG (2003) Gene amplification in esophageal adenocarcinomas and Barret's with high-grade dysplasia. Clin Cancer Res 9:4819-4825.

Miyamoto R, Uzawa N, Nagaoka S, Hirata Y and Amagasa T (2003) Prognostic significance of Cyclin D1 amplification and overexpression in oral squamous cell carcinomas. Oral Oncol 39:610-618.

Moreno-Bueno G, Rodriguez-Perales S, Sanchez-Estevez C, Hardisson D, Sarrio D, Prat J, Cigudosa JC, Matias-Guiu X and Palacios J (2003) Cyclin D1 gene (CCND1) mutations in endometrial cancer. Oncogene 22:6115-6118.

Nadal A and Cardesa A (2003) Molecular biology of laryngeal squamous cell carcinoma. Virchows Arch 442:1-7.

Nagasawa S, Onda M, Sasajima K, Makino H, Yamashita K, Takubo K and Miyashita M (2001) Cyclin D1 overexpression as a prognostic factor in patients with esophageal carcinoma. J Surg Oncol 78:208-214.
Nakakuki K, Imoto I, Pimkhaokham A, Fukuda Y, Shimada Y, Imamura M, Amagasa T and Inazawa J (2002) Novel targets for the $18 \mathrm{p} 11.3$ amplification frequently observed in esophageal squamous cell carcinomas. Carcinogenesis 23:19-24.

Nessling M, Solinas-Toldo S, Wilgenbus KK, Borchard F and Lichter P (1998) Mapping of chromosomal imbalances in gastric adenocarcinoma revealed amplified protooncogenes MYCN, MET, WNT2, and ERBB2. Genes Chromosomes Cancer 23:307-316.

Ohta JI, Miyoshi Y, Uemura H, Fujinami K, Mikata K, Hosaka M, Tokita Y and Kubota Y (2001) Fluorescence in situ hybridization evaluation of c-erbB-2 gene amplification and chromosomal anomalies in bladder cancer. Clin Cancer Res 7:2463-2467.

Ormandy JO, Musgrove EA, Hui R, Daly RJ and Sutherland RL (2003) Cyclin D1, EMS1, and 11q13 amplification in breast cancer. Breast Cancer Research and Treatment 78:323-335.

Ozawa S, Kitagawa Y and Kitajima M (2002) Molecular alterations in esophageal cancer. Nippon Geka Gakkai Zasshi 103:457-462.

Pedeutour F, Maire G, Sirvent N, Groupe francophone de cytogenetique oncologique (2004) From cytogenetics to cytogenomics of adipose tissue tumors: 2. Malignant adipose tissue tumors. Bull Cancer 91:317-323.

Perel Y, Valteau-Couanet D, Michon J, Lavrand F, Coze C, Bergeron C, Notz A, Plantaz D, Chastagner P, Bernard F, Thomas C and Rubie H (2004) Prognosis of neuroblastoma in childhood. Methods of assessment and clinical use. Arch Pediatr 11:834-842.

Preter K, Speleman F, Combaret V, Lunec J, Laureys G, Eussen BH, Francotte N, Board J, Pearson AD, Paepe A, Van Roy N and Vandesompele J (2002) Quantification of MYCN, DDX1 and NAG gene copy number in neuroblastoma using a real-time quantitative PCR assays. Mod Pathol 15:159166.

Rabbani F and Cordon-Cardo C (2000) Mutation of cell cycle regulators and their impact on superficial bladder cancer. Urol Clin North America 27:83-102.

Ramsay G, Stanton L and, Schwab JM (1986) Human proto-oncogene $\mathrm{N}$-myc encodes nuclear proteins that binds DNA. Mol Cell Biol 6:4450-4457.

Robanus-Maandag EC, Bosch CA, Kristel PM, Hart AA, Faneyte IF, Nederlof PM, Peterse JL and van de Vijver MJ (2003) Association of C-MYC amplification with progression from the in situ to the invasive stage in C-MYC-amplified breast carcinomas. J Pathol 201:75-82.

Ross JS and Gray GS (2003) Target therapy for cancer: The HER-2/neu and Herceptin story. Clin Leadersh Manag Rev 17:333-340.

Ross JS, Fletcher JA, Bloom KJ, Linette GP, Stec J, Symmans WF, Pusztai L and Hortobagyi GN (2004) Targeted therapy in breast cancer: The HER-2/neu gene and protein. Mol Cell Proteomics 3:379-398.

Rubie H, Hartmann O and Michon J (1997) N-MYC gene amplification is a major prognostic factor in localized neuroblastoma: Results of the French NBL 90 study; neuroblastoma Study Group of the Societe Francaise d'Oncologie Pediatrique. J Clin Oncol 15:1171-1182.

Saikawa Y, Kubota T, Otani Y, Kitajima M and Modbim IM (2001) Cyclin D1 antisense oligonucleotide inhibits cell growth stimulated by epidermal growth factor and induces 
apoptosis of gastric cancer cells. Jpn J Cancer Res 92:11021109.

Sarasin A (2003) An overview of the mechanisms of mutagenesis and carcinogenesis. Mut Research 544:99-106.

Schulz WA, Jankevicius F, Gerharz CD, Kushima M, van Roeyen CRC, Gobel P and Schimitz-Drager BJ (1998) Predictive value of molecular alterations of the prognosis of urothelial carcinoma. Cancer Detect Prevent 22:422-429.

Schwab M (1988) The myc-box oncogenes. In: Reddy EP, Skalka AM and Curran T (eds) The Oncogene Handbook, Elsevier Pub. Co., New York, pp 583.

Schwab M, Corvi R and Amler LC (1995) N-MYC oncogene amplification: A consequence of genomic instability in human neuroblastoma. Adv Cancer Res 47:235-281.

Schwab M (1999) Oncogene amplification in solid tumours. Cancer Biology 9:319-325.

Schwab M (2004) MYCN in neuronal tumours. Cancer Letters 204:179-187.

Scott D, Elsden J, Pearson A and Lunec J (2003) Genes co-amplified with MYCN in neuroblastoma: Silent passengers or co-determinants of phenotype? Cancer Letters 197:81-86.

Simon R, Struckmann K, Schraml P, Wagner U, Forster T, Moch H, Fijan A, Bruderer J, Wilber K, Mihatsch MJ, Gasser T and Sauter G (2002) Amplification pattern of 12q13-q15 genes (MDM2, CDK4, GLI) in urinary bladder cancer. Oncogene 21:2476-2483.

Sinclair CS, Rowley M, Naderi A and Couch FJ (2003) The 17q23 amplicon and breast cancer. Breast Cancer Res Treat 78:1328-1334.

Slamon DJ, Boone RC, Seeger DE, Keith V, Chazin HC, Lee LM and Souza LM (1986) Identification and characterization of the protein encoded by the human N-myc oncogene. Science 232:768-772.

Solovei I, Kienle D, Little G, Eils R, Savelyeva L, Schwab M, Jager W, Cremer C and Cremer T (2000) Topology of double minutes (dmins) and homogeneously staining regions (HSRs) in nuclei human neuroblastoma cell lines. Genes Chromos Cancer 29:297-308.

Squire J, Goddard AD, Canton M, Becker AM, Phillips RA and Gallie BL (1986) Tumour induction by the retinoblastoma mutation is independent of $\mathrm{N}$-myc expression. Nature 322:555-557.

Squire JÁ, Thorner S, Weitzman S, Maggi JD, Dirks P, Doyle J, Hale M and Godbout R (1995) Co-amplification of MYCN and a DEAD box gene (DDX1) in primary neuroblastoma. Oncogene 10:1417-1422.

Sunde M, McGrath KC, Young L, Matthews JM, Chua EL, Mackay JP and Death AK (2004) TC-1 is a novel tumorigenic and natively disordered protein associated with thyroid cancer. Cancer Res 64:2766-2773.

Sunpaweravong P, Sunpaweravong S, Puttawibul P, Mitarnum W, Zeng C, Baron AE, Franklin W, Said S and Varella-Garcia $M$ (2005) Epidermal growth factor receptor and cyclin D1 are independently amplified and overexpressed in esophageal squamous cell carcinoma. J Cancer Res Clin Oncol 131:111-119.

Tahara E (2004) Genetic pathways of two types of gastric cancer. IARC Sci Publ 157:27-349.

Takehana T, Kunitomo K, Kono K, Kitahara F, Iizuka H, Matsumoto Y and Fujino MA (2002) Status of c-erbB-2 in gastric adenocarcinoma: A comparative study of immunohistoche- mistry, fluorescence in situ hybridization and enzymelinked immuno-sorbent assay. Int J Cancer 98:833-837.

Tanner MM, Tirkkonen M, Kallionemi A, Isola J, Kuukasjarvi T, Collins C, Kowbel D, Guan XY, Trent J, Gray JW, Meltzer $P$ and Kallionemi OP (1996) Independent amplification and frequent co-amplification of three nonsyntenic regions on the long arm of chromosome 20 in human breast cancer Cancer Res 56:3441-3445.

Tsugawa K, Yonemura Y, Hirono Y, Fushida S, Kaji M, Miwa K, Miyazaki I and Yamamoto H (1998) Amplification of the c-met, c-erbB-2 and epidermal growth factor receptor gene in human gastric cancers: Correlation to clinical features. Oncology 55:475-481.

Tsujimoto H, Sugihara H, Hagiwara A and Hattori T (1997) Amplification of growth factor receptor genes and DNA ploidy pattern in the progression of gastric cancer. Virchows Arch 431:383-389.

Varis A, Wolf M, Monni O, Vakkari ML, Kokkola A, Moskaluk C, Frierson H Jr, Powell SM, Knuutila S, Kallioniemi A and El-Rifai W (2002) Targets of gene amplification and overexpression at $17 \mathrm{q}$ in gastric cancer. Cancer Res 62:26252629.

Vasudevan AS and Nuchtern JG (2005) Gene profiling of high risk neuroblastoma. World J Surg, in press.

Vidgren V, Varis A, Kokkola A, Monni O, Puolakkainen P, Nordling S, Forozan F, Kallioniemi A, Vakkari ML, Kivilaakso E and Knuutila S (1999) Concomitant gastrin and ERBB2 gene amplifications at 17q12-q21 in the intestinal type of gastric cancer. Genes Chromosomes Cancer 24:2429.

Vielba R, Bilbao J, Ispizua A, Zabalza I, Alfaro J, Rezola R, Moreno E, Elorriaga J, Alonso I, Baroja A and de la Hoz C (2003) p53 and cyclin D1 as prognostic factors in squamous cell carcinoma of the larynx. Laryngoscope 113:167-172.

Watters AD, Latif Z, Forsyth A, Dunn I, Underwood MA, Grigor KM and Bartlett JM (2002) Genetic aberrations of c-myc and CCND1 in the development of invasive bladder cancer. Br J Cancer 87:654-658.

Weber A, Imish P, Bergmann E and Christiansen H (2004) Coamplification of DDX1 correlates with na improved survival probability in children with MYCN-amplified human neuroblastoma. J Clin Oncol 22:2681-2690.

Wunder JS, Eppert K, Burrow SR, Gokgoz N, Bell RS and Andrulis IL (1999) Co-amplification and overexpression of CDK4, SAS and MDM2 occurs frequently in human parosteal osteosarcomas. Oncogene 18:783-788.

Yakut T, Egeli U and Gebitekin C (2003) Investigation of c-myc and $\mathrm{p} 53$ gene alterations in the tumor and surgical borderline tissues of NSCLC and effects on clinicopathologic behavior: By the FISH technique. Lung 181:245-258.

Yang ZQ, Donna A and Ethier SP (2004) Genomic organization of the $8 \mathrm{p} 11 \sim \mathrm{p} 12$ amplicon in three breast cancer cell lines. Cancer Genet and Cytogenet 155:57-62.

Zajac-Kaye M (2001) Myc oncogene: A key component in cell cycle regulation and its implication for lung cancer. Lung Cancer 34:43-46.

Zimmermman KA, Yancopoulos RG, Collum RK, Smith NE, Kohl KA, Denis MM, Nau ON, Witte D and Toran-Allerand CE (1986) Differential expression of myc family genes during murine development. Nature 319:780-783.

Associate Editor: Emmanuel Dias Neto 